\title{
Towards a Theory of Local Governance and Public Goods Provision
}

\author{
David Booth*
}

\begin{abstract}
Under-provision of essential public goods is making development in Africa slower and more inequitable than it needs to be. $A$ good part of this problem concerns the governance of provision at sub-national levels. This article provides a mid-term report on a multi-country research effort to shed light on the institutional sources of variation in local public goods provision. The particular focus is on key bottlenecks to improvement in maternal mortality, water and sanitation, facilitation of markets and enterprise, and public order and security. Drawing on fieldwork evidence and secondary literature, it identifies three clusters of issues and associated explanatory variables which seem to account for much of the variation in intermediate outcomes. They concern the extent of policy-driven incoherence in the institutional framework, the strength of corporate disciplines in provider organisations and the degree to which self-help is able to be 'locally anchored' in two particular senses.
\end{abstract}

\begin{abstract}
1 Introduction
Twenty years after international development organisations and local advocacy groups began actively promoting institutional reform and 'good governance' in Africa, the prevailing arrangements still fail to address the underprovision of basic public goods. As a consequence, development is needlessly slow and inequitable, especially in comparison with that which has been achieved elsewhere in the developing world.
\end{abstract}

A particularly important subset of issues linking insufficient provision of basic public goods with institutional shortcomings is to be found at the level of sub-national or local-area governance. Many of the public goods that are essential to economic growth and poverty reduction are provided at a local level if they are provided at all. Yet, despite the international community's 20-year love affair with democratic decentralisation - still often regarded as the key to better governance at sub-national levels - in most countries this is the level at which public goods provision is least adequate. Understanding of why this is the case remains patchy.

Generating some policy-relevant theory which does a better job of making sense of the evidence on local governance and public goods provision is therefore a high priority.
Is local governance a field in which there is scope for doing better by 'working with the grain' or otherwise embedding institutional arrangements in local realities? This article offers an initial set of answers to that question. It is written at the mid-point of the research in the APPP's Local Governance and Leadership stream and is primarily based on two sources: (1) team-based field research carried out in 2009 in four countries - Malawi, Niger, Rwanda and Uganda - with additional material from individual researchers in Senegal and Sierra Leone (see Workman, this IDS Bulletin), and (2) an extended search of the relevant literature. The 2009 fieldwork was designed mainly as a prelude to further and more extended empirical work, which is now taking place in Malawi, Niger, Rwanda and Uganda and two additional countries (Senegal and Tanzania). Nevertheless, it generated enough evidence and insight to support a preliminary analysis of findings. The extended literature search aimed to fill some of the more obvious gaps in empirical coverage and also to seek out more refined conceptual tools for ordering our findings and setting an appropriate agenda for the next phase.

\subsection{Research approach}

The Local Governance research stream is based on in-depth studies using a standard menu of

IDS Bulletin Volume 42 Number 2 March 2011 (c) 2011 The Author. IDS Bulletin (? 2011 Institute of Development Studies Published by Blackwell Publishing Ltd, 9600 Garsington Road, Oxford OX4 2DQ, UK and 350 Main Street, Malden, MA 02148, USA 
ethnographic methods in sets of purposively selected field sites. Analysis is comparative across sites and sectors within each study country. Our aim is to discover empirically grounded theoretical propositions by working on the actual variations we are able to observe in the 'real governance' (Olivier de Sardan 2008a) of public goods provision, across space and through time. We aim to construct some grounded middle-range theory which can be refined and tested in further research by ourselves and others, and become the basis for more intelligent policy-thinking.

The research took as its point of departure the institutions and processes involved in the provision of key public goods in four fields:

- Safe motherhood

- Water and sanitation

- Facilitation of enterprise and markets

- Public order and security.

Reducing the still shocking rates of maternal mortality in the poorest countries is a global priority endorsed by the World Health Organization (WHO), one that continues to pose huge challenges, especially in the more isolated rural areas. Drinking water and sanitation are fundamental public health issues. As with safe motherhood, the technologies are well known and hardly new. Geography and climate make many aspects more difficult, but there is no question that the principal barriers to improvement are institutional. Markets and enterprise are flourishing in most places, but in most places too, the breakthrough into longer distance and larger scale transactions has been far slower in Africa than in other comparable parts of the world, and the quality of local governance is at least part of the problem. Last but not least, the poorest parts of the region are also dangerous places, particularly for the physically, socially or economically disadvantaged. This is at least partly because the public good of protection against physical and sexual violence and extreme forms of oppression is frequently non-existent.

Some of the country exercises covered all four areas of public goods provision, while others concentrated on either the first two or the second two. The fieldwork focused particularly on the conditions appearing to favour or inhibit the addressing of key bottlenecks in provision. Across most field sites, shortcomings in provision were frequent and seemed to be associated with similar immediate constellations of causes. The somewhat less frequent examples of success in addressing the bottlenecks often appeared to be associated with the absence of these same factors. Despite the obvious differences in country contexts, we have also been able to identify commonalities at the level of wider institutional conditions and the effects of historical changes.

\subsection{Emerging findings}

The article discusses briefly three clusters of issues which have emerged as significant in these investigations. It is not entirely clear at this point whether the factors identified are all equally important and whether getting all three of them right is both necessary and sufficient for improving outcomes. However, it does seem clear that each is individually important across a wide range of particular circumstances in different countries and periods, and that together they account for a good part of the variation in the intermediate outcomes that concern us.

The differences in outcomes across the cases seem to be connected in the first instance with the degree to which:

- the policy-driven components of the institutional framework of public goods provision reflect a coherent vision, so that resources are allocated and incentives are structured in ways that are mutually reinforcing, not mutually undermining;

- the human-resource components of provision are subject to corporate performance disciplines, even if in other respects the organisational context is severely lacking in the attributes of a well-resourced and well-regulated bureaucracy; and

- there are institutions enabling local collective action which are locally anchored, in a double sense - the rules they incorporate are geared to local problem-solving, and they make use of institutional elements drawing on local cultural repertoires which motivate, enable and guide individuals to take particular actions.

In this summary form, our propositions may seem to capture three desiderata of development management, which are reflected rather generally 
in strategies for governance reform, including donor-inspired 'good governance' programmes. However, that would be a misunderstanding. As we shall explain, our concept of what needs to change is in some respects modest compared with the good governance orthodoxy, which tends to be wildly overambitious (Grindle 2007). In other respects, it enters territory where international policy thinking has lagged seriously behind research. In both respects, we would claim to be more realistic.

\section{Policy-driven institutional incoherence}

In several fields of public goods provision, our preliminary research has uncovered more or less serious problems of what we propose to call policy-driven institutional incoherence. Arrangements reflecting a consistent policy vision were found to be the exception rather than the norm. In most places, efforts to address key bottlenecks were obstructed not only by irreversible historical legacies but also by one or both of two types of policy-induced incoherence: persistently ill-defined mandates or overlapping jurisdictions among all or some of the organisations concerned; and perverse incentives confronting actors within particular organisations as a result of incomplete implementation of a new policy and/or the simultaneous pursuit of several policies which for practical purposes are in conflict. Our findings converge with each other and with a much wider literature in singling out the same pair of wider institutional factors as responsible for these problems: populist (especially presidential) policymaking, and the incentive effects of a high level of external donor funding.

\subsection{Sources of incoherence}

Under today's conditions of economic and political liberalisation, almost all public goods' provision in sub-Saharan Africa takes the form of co-production by several actors, including both formal organisations and informal collaborations between individuals or groups (Joshi and Moore 2004; Olivier de Sardan 2009). Typical delivery configurations cut across the public and private sectors and involve some measure of formal or 'informal' privatisation of what was once public provision (Blundo 2006; Blundo and Olivier de Sardan 2006; Blundo and Le Meur 2008; Olivier de Sardan 2008b). These arrangements can be more or less effective from the point of view of outcomes.
An important determinant of the quality of the outcome is whether the co-production in question is based on a real coordination of efforts among the actors, and on incentive structures which are consistent. A common pattern is one in which organisational mandates or jurisdictions are so (ill-) defined that they obstruct coordination and weaken the exploitation of complementarities. Staff in organisations face inconsistent incentives and pressures, because of the way these are bound up with institutions (e.g. of chieftaincy), policies or reform initiatives that have passed in and then out of favour without ever being fully implemented, properly wound up or comprehensively replaced.

The details of course, do vary. However, behind the particular manifestations we find a remarkably persistent set of wider institutional influences. There are two common features:

(1) the superimposition of successive waves of public sector reform, often under donor influence, without sufficient efforts to resolve the inconsistencies thereby created; and (2) populist policy initiatives, especially by presidents before and during election campaigns, without consultation with the affected sector planners (or donors) and without consideration of the resource implications.'

This describes a very widespread and perhaps increasingly institutionalised pattern. However, it is not absolutely universal, even across the relatively small number of countries included in our study. Under both historical regimes and one of the current regimes, problems of this type have been much less striking, meaning that we are entitled to treat policy-induced institutional incoherence as a variable influencing the quality of local governance and public goods provision, and not as a constant to be accepted as inevitable.

\subsection{Country variations}

In Malawi the boundaries of extension planning areas, agriculture development divisions, health departments and educational zones do not coincide. The jurisdictions and mandates of parastatals, elected politicians, chiefs and city authorities overlap in ways that produce confused responsibilities and contribute to weak coordination. These complications are not inevitable. There were fewer during Malawi's first two or three decades of independent government, because at that stage there were 
fewer layers of complexity and there was a clearer overall policy vision.

In Niger, under the last civilian regime, Heavily Indebted Poor Country (HIPC) resources were channelled into a Presidential Special Programme, whose infrastructure investments were largely disconnected from other aspects of public provision. For example, the purchase of ambulances - a part of the solution to a key bottleneck in the improvement of maternal mortality rates - was not joined up with other parts of the solution: the fuel, maintenance and staffing of emergency evacuation of mothers to higher health facilities. This forms part of a wider pattern in which populist measures of infrastructure provision are delinked from, if not in direct conflict with, the resource planning of line ministries.

At a somewhat more subtle level, primary health provision, including aspects bearing on mother and child health, is currently being undermined by unresolved contradictions between two reforms of healthcare financing. In Niger, as in other countries of the region, a policy of offering 'free' primary healthcare to under-fives was adopted on a populist basis in 2006, without several of the preconditions for its success, including a budget. This was superimposed on a functioning cost-recovery (health insurance) system inspired by the Bamako Initiative. The cost-recovery arrangements have continued to operate in principle for the minority of patients who are adults not covered by other exemptions, but it has been seriously undermined. Health units have lost their only reliable source of nonsalary funding. The result has been a significant weakening of provider incentives in the public sector and a considerable expansion of de facto privatisation (Olivier de Sardan et al. 2010b).

In Uganda, Health Districts do not coincide with administrative districts, and the latter are constantly changed by presidential decisions linked to a highly clientelistic form of neopatrimonial politics. The fact that Health Districts do not map onto administrative districts is not the only factor accounting for the almost non-existent involvement of local administrators and politicians in monitoring and quality control of health centres found in our sites, but it seems an important contributory factor. Formal responsibilities for coordination around public health issues are not complied with, in part because the structure discourages it (Kawooya Ssebunya 2010).

On the face of it, Rwanda seems to be the only current example where, at least in the health field, the institutional framework has been rendered reasonably coherent. Our preliminary fieldwork, which was limited to one 'sector' in a single district, suggested the importance of (1) a recent reform of boundaries and mandates covering the whole country and all line ministries;

(2) a healthcare reform in which incentives appear consistent (affordable health insurance plus strong pressure to use it); and (3) a donorcoordination arrangement promoted by central government that seems to be working down to district level (Golooba-Mutebi et al. 2010).

\section{Presence or absence of corporate disciplines}

In the study countries, difficulties in addressing key bottlenecks in provision are almost always linked to general resource shortages, often of an extreme kind. However, our preliminary research uncovered many instances where these problems were compounded by more or less serious weaknesses in either the allocation or the performance of the available human resources (technical and administrative staff). In many cases, unresolved problems in public provision could be attributed directly to an absence of the disciplines expected within any hierarchically ordered organisation: rules not being clearly laid down or enforced, instructions not being followed, vital jobs not being done, and so on. Thus, the issues of horizontal incoherence reviewed in the last section were often compounded by shortcomings in the vertical structures of control and supervision within particular provider organisations.

\section{$3.1 \mathrm{~A}$ realistic perspective}

That we have found major problems of this sort is not surprising or, in itself, particularly interesting. Something like this has formed the common premise of donor-supported public-sector reform efforts for at least a quarter of a century. One of the starting points of the APPP is the relatively recent but now quite substantial body of research which, for a number of sub-Saharan African countries, documents in precise detail the ways in which behaviour in public-sector organisations, including service-delivery organisations, fails to correspond to the 'expected' pattern (Blundo and 
Olivier de Sardan 2006). For some countries, this includes a convincing historical narrative of how things came to be the way they are (Anders 2001; Golooba-Mutebi 2007; Anders 2008; Olivier de Sardan 2008b; Becker 2009). This research portrays a situation which is more complex than implied by the standard account of public sector deterioration underlying the 'Washington Consensus'. However, in so doing it only deepens the appreciation that outcomes for those who are at the receiving end of public goods provision are abysmal in most places most of the time, for reasons that have much to do with the breakdown of corporate disciplines.

The APPP aims not just to add to this literature but to explore the previously neglected topic of whether and why there are exceptions and variations within the general pattern. Thus, its research stream on State Bureaucracies is exploring whether the 'informal privatisation' of services by public-sector personnel is invariably exploitative and harmful from the point of view of users. It is seeking out examples of 'microreforms' in which managers take advantage of the discretion they enjoy de facto to reorganise provision. These measures may be contrary to the formal rules but nevertheless 'work', not just from the providers' point of view but also, in places and to some extent, from the point of view of users.

In the same spirit, our concern in this section is with the issue of variations and exceptions. In pursuing this enquiry, we are not very much interested in the possibility that a well-resourced, rule-governed bureaucracy subject to effective democratic controls might be the ideal way of providing many types of public goods. This is appealing in the abstract but almost entirely irrelevant to the reality of sub-Saharan Africa and other very poor world regions. Instead, our focus is on the possibility that the presence or absence of corporate performance disciplines within provider organisations makes a significant difference even when in most other respects the circumstances are not conducive to good performance, in particular when the sociopolitical context and professional norms retain important patrimonial or clientelistic features.

\subsection{Two types of departure from the norm of harmful clientelism}

Two kinds of departure from the general pattern may be distinguished in principle. The first is what Leonard (2010) calls 'pockets' of effectiveness within weak-governance states specific agencies or offices where, because of changes stopping short of outright privatisation, staff disciplines are maintained or enhanced in the face of the prevailing logics of behaviour in the national political system and within the public service at large. The second type of variation is that which can be observed across a wide range of different public sector bodies between periods or across countries and relates to the way the prevailing logics of behaviour work themselves out under different types of broadly neo-patrimonial political regime.

From the APPP fieldwork, the most interesting examples so far of pockets of effectiveness are those concerning the franchising of the management of transport stations to corporate bodies of a trade-union or business-association type. We have examples of this from Niger and clear suggestions of something similar in early reports from Senegal (Gómez-Temesio 2010; Olivier de Sardan et al. 2010a). In both cases, the management tasks performed involve the provision of public or collective goods relating to time schedules, security and hygiene. In some respects, the arrangements may be best analysed as the solution to a problem of collective action among the immediate participants, drivers or vehicle owners. However, they are also in effect the product of the state's delegating key functions including policing and tax collection ${ }^{2}$ to a non-state body and achieving thereby an institutional arrangement which remains imperfect (still in important respects corrupt and faction-ridden) but nonetheless displays a relatively high degree of corporate discipline and thus effectiveness in much of what it does.

Turning to variation across countries and periods, we have a predictably abundant crop of examples of highly clientelistic forms of political rule which in practice have the effect of undermining the ability of the public administration to perform as it is 'supposed' to. On the other hand, from one current case (Rwanda), from relatively recent history (Malawi) and from somewhat more distant history (Côte d'Ivoire, Kenya, Tanzania, Uganda, etc.), we know that clientelistic undermining of bureaucratic functioning is a variable and not a fixed given. Furthermore, the secondary literature on Africa and Asia agrees with our own country studies in suggesting that 
where bureaucracies function relatively well in public-goods provision, this is not necessarily because neo-patrimonial logics of behaviour are absent from the national political system (Centre for the Future State 2010; Kelsall et al. 2010).

Our preliminary research in Niger has generated a particularly rich account of the way clientelistic appointments prevent a rational allocation of human resources in the health sector, and the enforcement of even minimal standards of performance. Throughout the sector, coherent management of staff postings is extremely difficult, with the result that rural health units are frequently understaffed and urban ones overstaffed. Efforts by managers to correct these anomalies are routinely undermined when midwives and medical personnel 'pull strings' in the capital to get them overturned (Diarra 2009).

A contrasting picture emerges from the preliminary research done by our team in Rwanda. Their findings remain to be fleshed out and validated, but they indicate a situation in at least one locality which contrasts sharply not only with Niger but also with Malawi and Uganda, at least in respect of staff discipline and performance relating to safe motherhood. Whereas in all the study countries the official policy now is to get mothers to give birth with the assistance of trained professionals, only in Rwanda have we found this being rigorously enforced. A combination of fines and active public education seems to be producing a high level of compliance. Staff disciplines seem to be effective, so rules are more likely to be enforced and education campaigns are carried out. The pattern of abusive treatment in health centres observed nearly everywhere else appears less common, so that the relative attractiveness to mothers of home birthing is reduced (GoloobaMutebi et al. 2010).

\subsection{Bureaucratic disciplines and political regime types}

Because of the relative recentness of some of its key transitions, Malawi provides a good source of examples relating to differences across regimes and time-periods, as illustrated by Diana Cammack's contribution to this IDS Bulletin. Malawi suggests that some kinds of neopatrimonial presidential system and their behavioural logics utterly undermine the discipline of the public bureaucracy, including the lower tiers of the hierarchy. Other kinds allocate patronage in ways that do not destroy bureaucratic disciplines. The late Muluzi and early Banda presidencies exemplify the two types. In the second type, it is not necessary for authority to be either finely calibrated or rulebound, and the bureaucrats do not need to be highly trained, appointed purely on merit, well remunerated or (in the East Africa jargon) well 'facilitated'.

The evidence suggesting the possibility of bureaucratic effectiveness under regimes of a neo-patrimonial type raises questions about the contributions of 'democracy'. The balance of evidence indicates that the bottom-up control which is generated by actually existing 'democracy' in sub-Saharan Africa is at best a weak source of countervailing disciplines. At worst, it is an additional factor helping to excuse or legitimise rule-breaking by officials and/or non-enforcement of rules. This refers first to the macro-level transition from relatively authoritarian, single-party, regimes to relatively liberal, in principle multi-party, regimes; and then to the second step of making competitive politics the basis of sub-national government as well.

The Uganda field report tells us that 'for many rural dwellers in Uganda, democratic processes seem to mean freedom from civic obligations. This has detrimental effects on collective action efforts and the enforcement of laws to facilitate them' (Kawooya Ssebunya 2010). The introduction of downward accountabilities in the form of local competitive elections appears to provide only a poor substitute for top-down disciplines. It also has considerable power to obstruct the ability of officials to provide the sort of public goods that are about mitigating the negative externalities associated with uncontrolled behaviour by individuals or households - for example, formulating and enforcing by-laws, or conducting public education campaigns, to prevent outbreaks of disease or environmental disasters. Unlike appointees, elected officials like Uganda's Council (LC5) Chairmen - and civil servants who report to elected officials, including the Chief Administrative Officers (CAOs) in Ugandan districts - are typically reluctant to enforce by-laws which are unpopular with the population, because they expect this will lose them votes (Kawooya Ssebunya 2010). 
In contrast, Rwanda today may exemplify the kind of balance between corporate bureaucratic discipline and local participatory processes, which avoids the persistent failures in local public goods provision that are observed in our other present-day cases. The national political system is generally recognised to contain a mixture of controlled political inclusion and relatively authoritarian democracy. The imihigo system, to which our study largely attributes some of the relatively impressive outcomes in the first field site, is an unusual form of multi-level performance contract. It depends on both rewards and sanctions, some of them drawing on neo-traditional concepts of honour and shame. It is made effective by means of a strong element of top-down pressure, ultimately from President Kagame, with smaller but not insignificant elements of engagement by local populations (Golooba-Mutebi et al. 2010).

\section{Locally anchored problem solving}

The third cluster of issues which seems important concerns the feasibility of local collective action to address key bottlenecks in public goods provision. We are interested in the features of the institutional context that either facilitate or hinder such action.

The combined evidence seems clear in suggesting that some of the typical ways in which local self-help is structured in aid-dependent African countries are either unsustainable or accompanied by socially harmful side-effects. On the other hand, this approach does not seem either inevitable or completely universal. In a number of our countries, self-help was markedly more real and effective in the still-remembered past, for reasons that can be identified. And for the present period, we think there are examples which point clearly in an alternative direction.

\subsection{Associational models in question}

The approach we propose to call 'associational' has been strongly promoted by official aid donors, where it is seen as the natural counterpart of building or rebuilding the legalrational foundations of the state. It is central to the concepts of 'civil society strengthening' and 'building the demand side of good governance' that have informed the work of the World Bank and many bilateral agencies since the 1990s. For rather longer, it has been part of the core ideology of most northern non-governmental organisations (NGOs). These days, it is also very much part of the way of thinking and working of national and local governments, thoroughly 'appropriated' by them, if in a more or less distorted form (Olivier de Sardan 2009). Its centrepiece is the organisational model of the 'voluntary association'.

Voluntary associations have members (and thus non-members), formalised rules (and thus formal sanctions), governance arrangements (and thus scope for use and abuse of power) and funding needs (and thus a host of accounting and reporting problems). Even when they take the form of community-based organisations (CBOs), in which in principle the membership is co-extensive with the local population, these requirements remain.

The burden of a large case study literature is that initiatives based on the associational model tend not to work, or not in the way their promoters intend. They create new forms of inequality, increase materialistic motivations and quite often promote corruption and clientelism among leaders. They are divisive from a social point of view, privileging those who have the education and other skills needed to comply with the funder's requirements. They tend to get diverted from addressing people's real problems (pulled instead into the donor world of 'finding problems for solutions'), and often end up weakening the capacity for collective action, rather than strengthening it.

For example, Swidler and Watkins' (2009) account of NGO-promoted self-help on HIV/AIDS in Malawi is powerfully persuasive on the social downsides of the standard approach. Emphasising the way donor-funded projects become a source of social differentiation and exclusion, it echoes the arguments of Uvin (1998) about the negative social impacts of aid in pre-genocide Rwanda. Gugerty and Kremer (2008) studied external funding for women's community groups in Kenya using a quantitative impact assessment technique. The strongest effect they found was on group membership and leadership, these being skewed towards younger, better educated and better-off women. In this way, the groups gradually lost the characteristics that drew the funders to them in the first place.

Igoe (2003) has given us a detailed account of the effects of donor support to pastoralist land 
rights movements in East Africa, which involved turning them into NGOs. The energies of leaders were diverted into activities that could be justified in aid funding reports at the expense of the objectives and solidarities with which the movement started out. Several of the same themes recur in Dill's (2009) account of the lack of 'fit' between NGO-promoted CBOs and the local sociocultural environment in Dar es Salaam and Blundo's (2009) study of NGO sanitation initiatives in a Niger town.

The 2009 APPP research amplified several of these concerns. Our fieldwork has not so far touched upon social division and exclusion as an effect of the framing of self-help in an associational mode, partly because we are not focusing on projects as such. On the other hand, the field reports are littered with instances of NGO- or donor-initiated associations or committees failing to meet their intended or any other socially useful objective, and eventually collapsing, usually amid accusations of some sort of abuse of office. Often, one of the legacies of these experiences seems to be a further reduction in the willingness of individuals to engage in voluntary efforts or to continue making voluntary contributions for the collective good as they have in the past.

Contemporary urban Malawi is a good source of examples (see Cammack, this IDS Bulletin). In Niger, too, the 'committees' and other associational structures promoted by projects and development partners tend to 'end up being dissolved or falling asleep' (Olivier de Sardan et al. 2010a). With the single exception of the transport stations discussed above, sanitation and cleansing matters are seriously neglected, and the collective cleaning of public places which used to occur under the more authoritarian regimes of the past are now rare, the view now being that this is the responsibility of local government. The neighbourhood committees for the management of household waste which were established by the municipal authorities in two of the Niger study sites illustrate the problems with the alternative 'associational' approach (Issa 2009).

\subsection{Collective action and 'local reforms'}

At the same time as contributing negative examples of the above kinds, our preliminary fieldwork has begun to give us a handle on various departures from the standard associational model of self-help that seem to be working rather better. In this sense, it has put us on track to inferring a definite pattern of variation. The Niger experiences characterised by the country research team as 'local reforms' are particularly suggestive. A good example is the initiative under which a number of mayors have begun collecting 'a few additional centimes' from all users of primary healthcare facilities to fund the fuel and staff costs associated with emergency evacuations of pregnant women. The new fund and the contributions it requires are completely outside the national regimes of user charges and free care. It enables a solution to the otherwise difficult problem of addressing emergencies with the ambulances provided under the President's Special Fund (Diarra 2009; Olivier de Sardan et al. 2010a).

As this example illustrates, one of the things that distinguishes a 'local reform' from reforms in general is that it is locally initiated and oriented towards solving specific problems. The particular circumstances that have enabled promising 'local reforms' in the cases we have considered all seem to include the posing of a problem to which national policies and leaders are not offering solutions. They have also relied primarily, although not always exclusively, on mobilising local resources, and crucially they have not been driven by the availability of either government or donor funds. For this reason, externally prescribed organisational forms have not needed to be adopted, and it has been possible to draw on local views about what is important, proper and acceptable.

Another possibly important common feature of all of the examples mentioned here is that the initiatives have been non-exclusive - directed at whole populations of local people. In this and other respects, the country experience of Rwanda is relevant again here. Once a leading example of the negative effects of donor-inspired and government-enforced social engineering on the 'association' model (Uvin 1998), Rwanda appears now as a place where development initiatives are typically geared to whole populations. Incentives to local problem solving, as well as general directives and public education messages, are transmitted through the state apparatus. Local self-help is relatively vibrant, taking into account the terrible social legacies of the recent past, and this may owe something to 
the way the government - following in this respect its pre-1994 predecessors - uses neotraditional concepts to promote and get acceptance of cooperative ways of working (Golooba-Mutebi et al. 2010).

The common threads running through all of these examples are hard but not impossible to detect. Unlike the usual project-inspired initiatives, they do not require beneficiaries to sign up to principles of organisation of which they have little experience or understanding. On the contrary, there is an enabling institutional environment for local problem-solving initiatives which involve whole populations, make use of local resources and draw legitimacy and other strength from already existing and widely shared views on what is important and how to get things done - borrowing institutional elements from local cultural repertoires to avoid the high costs of inventing everything from scratch (Greif 2006; Booth, this IDS Bulletin).

\subsection{Implications}

If confirmed by further work, this finding has significant policy implications. It suggests that governments, donors and NGOs should be doing much less to 'support' local self-help in ways that conform to an externally motivated associational model, and much more to encourage local problem solving and cultural borrowing. In truth, aid donors have only been one of the important sources of inappropriate institutional technology transfer in post-colonial sub-Saharan Africa. This trail was blazed by the first post-independence generation of African leaders, with left-tending ideologues like Nyerere and Senghor in the vanguard. However, for recent decades, it is a

\section{Notes}

* This article draws heavily on the collective research of members of the Local Governance and Leadership stream of APPP, for which I express my gratitude while assuming full responsibility for the views and assessments it expresses.

1 The 'piling up' of donor-inspired institutional reforms is a long-established theme (Therkildsen 2000; Biershenk and Olivier de Sardan 2003; Kayizzi-Mugerwa 2003; Batley reasonable approximation to regard this as, first and foremost, an aid problem. This has implications for how the role of aid is visualised and how donor agencies equip themselves for their task, an issue which we look forward to tackling too.

\section{Conclusion}

If all of the foregoing is correct, we have the beginnings of a theory of local governance and public goods provision. That is, we have some propositions that appear to have a reasonable level of empirical support about not only what causes what, but also how it does so.

Further probing, elaboration and refinement of our claims regarding each of the three clusters of issues is clearly needed. Nevertheless, our initial findings seem to justify the conclusion that three variables are of particular, and underappreciated, importance in the first-level determination of differences in public goods outcomes: the extent of policy-driven incoherence in the institutional framework, the strength of corporate discipline in provider organisations and the extent to which self-help is able to be 'locally anchored' in two particular senses. We have also begun to single out a set of wider, inhibiting conditions which ought to be the focus of more policy discussion. They include the piling up of donor-inspired reform initiatives, compounded by on-the-campaign-trail policymaking; the relative frequency of the particular types of neo-patrimonial regime that undermine corporate disciplines in bureaucratic organisations; and the degree to which donor and NGO activity underpins the wrong kinds of institutionalisation of self-help.

and Larbi 2005; Olivier de Sardan 2009). The increasing popularity of populist, on-thecampaign-trail, policymaking, has also been a strong theme in recent work, although appreciations of it vary.

2 In regard to tax collection, the findings are comparable with those of studies of 'associational taxation' in Ghana and elsewhere undertaken by members of the Centre for the Future State (Joshi and Ayee 2008). 


\section{References}

Anders, G. (2008) 'Like Chameleons: Civil Servants and Corruption in Malawi', in G. Blundo and P.-Y. Le Meur (eds), The Governance of Daily Life in Africa: Public and Collective Services and their Users, Leiden: Brill: 119-42

Anders, G. (2001) 'Freedom and Insecurity: Civil Servants between Support Networks, the Free Market and the Civil Service Reform', in H. Englund (ed.), A Democracy of Chameleons: Politics and Culture in the New Malawi, Uppsala: Nordiska Afrikaininstitutet: 43-61

Batley, R. and Larbi, G.A. (2005) 'Capacity to Deliver? Management, Institutions and Public Services in Developing Countries', in Y. Bangura and G.A. Larbi (eds), Public Sector Reform in Developing Countries: Capacity Challenges to Improve Services, London: Palgrave Macmillan/UNRISD: 99-127

Becker, F. (2009) "Bad Governance" and the Persistence of Alternative Political Arenas: A Study of a Tanzanian Region', in G. Blundo and P.-Y. Le Meur (eds), The Governance of Daily Life in Africa: Ethnographic Explorations of Public and Collective Services, Leiden: Brill: 73-99

Biershenk, T. and Olivier de Sardan, J.-P. (2003) 'Powers in the Village: Rural Benin Between Democratisation and Decentralisation', Africa 73.2: 145-73

Blundo, G. (2009) 'Des Ordures et des Hommes: La Gouvernance de L'assainissement à Dogondoutchi', in J.-P. Olivier de Sardan and M. Tidjani Alou (eds), Les Pouvoirs Locaux au Niger, Tome 1: À la Veille de la Décentralisation, Dakar and Paris: CODESRIA/Karthala: 113-150

Blundo, G. (2006) 'Dealing with the Local State: The Informal Privatization of Street-Level Bureaucracies in Senegal', Development and Change 37.4: 799-819

Blundo, G. and Le Meur, P.-Y. (eds) (2008) The Governance of Daily Life in Africa: Ethnographic Explorations of Public and Collective Services, Leiden: Brill

Blundo, G. and Olivier de Sardan, J.-P. (2006) Everyday Corruption and the State: Citizens and Public Officials in Africa, London: Zed Books

Centre for the Future State (2010) An Upside Down View of Governance, Brighton: IDS

Diarra, A. (2009) 'La Prise en Charge de Laccouchement dans Trois Communes au Niger: Say, Balleyara et Guidan Roumji', draft paper, Niamey: Laboratoire d'Etudes et de
Recherches sur les Dynamiques Sociales et le Développement Locale (Lasdel)

Dill, B. (2009) 'The Paradoxes of Communitybased Participation in Dar es Salaam', Development and Change 40.4: 717-43

Golooba-Mutebi, F. (2007) 'Chiefs, Politicians, and the Community in Uganda: A HistoricoAnalytical Narrative', paper presented at the 4th National Annual Local Government Conference, Durban, South Africa

Golooba-Mutebi, F.; Chambers, V.; Munyaburanga, E.; Habiyonizeye, Y. and Rwabukumba, C. (2010) 'Delivering Public Goods in Rwanda: Early Findings from Nyamagabe District', draft Working Paper, London: Africa Power and Politics Programme

Gómez-Temesio, V. (2010) 'Régulation des Marchés et Assainissement de l'eau au Senegal: Rapport de L'enquête Initiée en Novembre 2009', paper presented at the APPP Local Governance Workshop, Paris

Greif, A. (2006) Institutions and the Path to the Modern Economy: Lessons from Medieval Trade, Cambridge: Cambridge University Press

Grindle, M. (2007) 'Good Enough Governance Revisited', Development Policy Review 25.5: 553-74

Gugerty, M.K. and Kremer, M. (2008) 'Outside Funding and the Dynamics of Participation in Community Associations', American Journal of Political Science 52.3: 585-602

Igoe, J. (2003) 'Scaling Up Givil Society: Donor Money, NGOs and the Pastoralist Land Rights Movement in Tanzania', Development and Change 34.5: 863-85

Issa, Y. (2009) 'Le Service Public de L'eau et de Lassainissement à Say, Guidan Roumdji et Belleyara', draft paper, Niamey: Laboratoire d'Etudes et de Recherches sur les Dynamiques Sociales et le Développement Locale (Lasdel)

Joshi, A. and Ayee, J. (2008) 'Associational Taxation: A Pathway into the Informal Sector?', in D. Bräutigam, O.-H. Fjeldstad and M. Moore (eds), Taxation and State-Building in Developing Countries: Capacity and Consent, Cambridge: Cambridge University Press: 183-211

Joshi, A. and Moore, M. (2004) 'Institutionalised Co-production: Unorthodox Public Service Delivery in Challenging Environments', Journal of Development Studies 40.4: 31-41

Kawooya Ssebunya, A. (2010) 'Public Goods Delivery in Uganda: Exploring Local Governance Forms and Leadership that Work 
for the Poor', paper presented at the APPP Local Governance Research Stream Workshop, Paris

Kayizzi-Mugerwa, S. (ed.) (2003) Reforming Africa's Institutions: Ownership, Incentives, and Capabilities, Tokyo: United Nations University Press/WIDER

Kelsall, T.; Booth, D.; Cammack, D. and Golooba-Mutebi, F. (2010) Developmental Patrimonialism? Questioning the Orthodoxy on Political Governance and Economic Progress in Africa, Working Paper 9, London: Africa Power and Politics Programme

Leonard, D. (2010) “Pockets" of Effective Agencies in Weak Governance States: Where are they Likely and Why Does it Matter?', Public Administration and Development 30: 91-101

Olivier de Sardan, J.-P. (2009) The Eight Modes of Local Governance in West Africa, Working Paper 4, London: Africa Power and Politics Programme

Olivier de Sardan, J.-P. (2008a) Researching the Practical Norms of Real Governance in Africa, Discussion Paper 5, London: Africa Power and Politics Programme

Olivier de Sardan, J.-P. (2008b) 'State Bureaucracy and Governance in Francophone West Africa: An Empirical Diagnosis and
Historical Perspective', in G. Blundo (ed.), The Governance of Daily Life in Africa: Ethnographic Explorations of Public and Collective Services, Leiden: Brill: 39-71

Olivier de Sardan, J.-P.; Abdulkader, A.; Diarra, A.; Issa, Y.; Moussa, H.; Oumarou, A. and Alou, M.T. (2010a) Local Governance and Public Goods in Niger, Working Paper 10, London: Africa Power and Politics Programme

Olivier de Sardan, J.-P.; Ridde, V.; Diarra, A. and Ousseini, A. (2010b) Pour une Réflexion sur la Gratuité des Soins au Niger, Note d'Information 1, Niamey: Laboratoire d'Etudes et de Recherches sur les Dynamiques Sociales et le Développement Locale (Lasdel), 'Programme Abolution du Paiement'

Swidler, A. and Watkins, S.C. (2009) “"Teach a Man to Fish": The Sustainability Doctrine and its Social Consequences', World Development 37.7: 1182-96

Therkildsen, O. (2000) 'Public Sector Reform in a Poor, Aid-Dependent Country, Tanzania', Public Administration and Development 20: 61-71

Uvin, P. (1998) Aiding Violence: The Development Enterprise in Rwanda, West Hartford, CT: Kumarian Press 